\title{
Design Without Final Goals: Getting Around Our Bounded Rationality
}

\author{
Jude Chua Soo Meng, \\ Nanyang Technological University, Singapore
}

\begin{abstract}
Herbert Simon's theory of design welcomes those unintended consequences of one's original design intention, with a view to integrating them as new final goals of one's design. Seen this way, design and design education has the powerful potential to broaden human preferences and discover new cultures, like a kind of liberal education. The basis of such an account of design is in the recognition of our bounded rationality and with that, the need to search for what we cannot too easily know - an idea for which he acknowledges a depth to James March. Indeed, March's own writings instantiate the same insight that we need to find strategic ways of exploring and searching for ideas that we are often blind to because of our cognitive limitations. Yet Simon's attentiveness to bounded rationality and the need for searching discovery is equally, if not more, indebted to Ludwig von Mises and F. A. Hayek. Hayek's ideas critical of Cartesian constructivism and the need to appreciate institutions such as the free market, which are the result of human action rather than design, parallel many aspects of Simon's theory of design without final goals. All three thinkers, Simon, March and Hayek, were painfully cognizant of the fact that human beings are not as smart as they think they are, and that we have to design strategies for outsmarting ourselves.
\end{abstract}

Keywords:

\section{INTRODUCTION}

Herbert Simon's theory of design welcomes those unintended consequences of one's original design intention, with a view to integrating them as new final goals of one's design (Simon, 1996, pp. 162-163). Seen this way, design and design education has the powerful potential to broaden human preferences and thinking like a kind of liberal education (Simon, 1996). The basis of such an account of design is in the recognition of our rationality's limitations and with that, the need to search for what we cannot too easily know - an idea for which he acknowledges a depth to James March. Indeed, March's own writings instantiate the same insight that we need to find strategic ways of exploring and searching for ideas that we are often blind to because of our cognitive limitations. Yet Simon's attentiveness to bounded rationality and the need for searching discovery is equally, if not more, indebted to Ludwig von Mises and F. A. Hayek.

This paper traces the likely source of Simon and March's ideas to Hayek. Hayek was critical of Cartesian constructivism and argued for the need to appreciate and favor undesigned institutions such as the free market (see Hayek, 1994). This line of thought in Hayek parallels many aspects of Simon's theory of design without final goals. Like Simon and March, Hayek was painfully cognizant of the fact that as human beings we are not as smart as we think we are, and that we had to design strategies for getting around our bounded rationality.

\section{HERBERT SIMON: DESIGNING WITHOUT FINAL GOALS}

For Herbert Simon, "everyone designs who devises courses of action aimed at changing existing situations into preferred ones" (Simon, 1969, p. 30). Although Herbert Simon's definition of design as the artificial transformation of things or events to arrive at a preferred state of affairs (or some close variant of that) is often used as a point of departure for an account of design, there is no general agreement on the soundness of Simon's theory of design. His The Sciences of the Artificial (1996), which unpacks an account of a science of design, has been criticized as a scientistic mischaracterization of what design really is. For instance, Nigel Cross (2001) worries that Simon's account of design as a kind of problem solving guided by instrumentalist technical rationality distorts what designers actually do, and how they think. Cross argues that design may actually be a 
unique kind of thinking, which Cross calls a "designerly way of knowing". Such a designerly way of knowing could have some affinity with what Donald Schön (1983) describes as "reflective practice", which generates different interpretations of what the design problem is. That is, the designer does not merely slavishly work out the best means to achieve a given goal; rather designing includes being able to offer new interpretations of what the goals are (Chua, 2009).

Critics of Simon's instrumentalist theory of design typically rely on the earlier editions of the Sciences of the Artificial (Chua, 2009). The third and final edition, however, seems to me to capture some very interesting accounts of what designing can be, which are absent in the earlier editions (see Chua 2009). Simon in that $3^{\text {rd }}$ edition speaks of what he calls "design without final goals" (Simon, 1996, p. 162). The general idea is this: When one designs, one might not fully foresee all the consequences that will follow from one's design plan. As these unintended and unforeseen consequences unfold following one's design, some of these consequences will be unwelcome. Others will be attractive. Even if attractive, these are of course not part of one's design plan. Typically, the designer might not think much of these consequences, even if attractive. As far as the designer is concerned, the aim is to achieve the pre-determined goal. If that goal is not achieved, the design has failed, and it does not matter that there are some welcome effects. But Simon's point is that we should not be too quick to thumb down the "failed" design. Simon's suggestion is for designers to consider adopting these welcome and unintended consequences as new goals in the design process, and to relax our fixation on the original goal. By designing without a fixation on final goals, and by adopting that stance to welcome new, emergent and originally unintended goals, design becomes a powerful tool for discovering new goals previously unforeseen.

With this analysis of design without final goals, Simon's so-called instrumentalist theory of design takes on a very different shape. Instead of slavishly working out the means to realise (a) given goal(s) implicit in a problem as defined, design now focuses on the search for new goals. This is very significant. Rittel and Webber (1973) argued that in the design of social policy, one deals typically with wicked problems. Wicked problems are problems that are often intractable and difficult to problematize in part because there are so many competing ways to define the "problem", given the high number of goals that different stakeholders can have. Since every different problematization of the phenomenon inevitably presupposes a value judgment about what is amiss or what valuable goals need to be achieved, and therefore what needs to be done to correct it, so each definition of the problem implicitly puts out a (design) "solution" different from the solution associated with another definition of the problem. This is very different from what under controlled conditions or in science, for instance, are "tame problems", where the goals are very clear or where there is consensus on the goals, and therefore stakeholders can come to an agreed definition of the "problem" (as well as the general solution). When dealing with tame problems, one would likely be reasoning in a instrumentalist manner towards that agreed goal. Whereas in the case of wicked problems, one has to think hard about what the problem is and therefore work with competing assessments of what the goal(s) are when designing a fitting solution: it is much more complex. In pitting wicked problems against tame problems and highlighting the fact that designers typically deal with the former, Rittel and Weber were resisting the impression that designers simply thought in an instrumentalist way (see Coyne, 2005, p. 6). Simon's account of design without final goals, which is a departure from his earlier instrumentalist account of design, now comes much closer to Rittel and Weber's insistence on the complexity and fluidity of design work. Like them, Simon would also agree that design negotiates competing, incommensurably different goals. Indeed, he suggests that, when a designer moves the design solution in a different direction upon discovering a new final goal, we should not be focused on evaluating whether the new design is "better or worse" than the original plan (Simon, 1996, p. 130). Instead, with a spirit of pluralism he welcomes them simply as different, and considers that design is often ruled by style (Simon, 1975; 1996). I would even venture to say that Simon's design theory makes problems (even more) wicked, because when the stylistic design without final goals proceeds, new goals are discovered and new (competing) conceptions of what the problem is and what the design solution should be also surface.

It is also useful to understand that for Simon, the task of searching for new goals through the practice of designing is very fitting. Because the human mind cannot grasp all the available consequences of one's actions given rationality's boundaries - a theme which he developed in his economic and psychological works when attacking the optimizing homo economicus (see Simon, 1997) - one should not pin too much hope on the human mind grasping, theoretically, all these potentially desirable goals. Instead, doing something to effect consequences is useful because it helps the consequences emerge 
that we cannot, as armchair philosophers, foresee. And one of those things one can do is to design. By designing, we could discover unexpected consequences that play out because of our own design plans. Some of these consequences searchingly emerged by design can be grasped as attractive, and can be welcomed as goals that we now, in hindsight, want to pursue. Note: this means that what are discovered by design are not merely the new goals, but new goals that, when so discovered, we may discover ourselves liking. In short, design not only reveals unintended or unforeseen consequences that may be welcome. Should these consequences later become desirable to us, then design also allows us to discover the "identities" we had not previously foreseen ourselves becoming. This happens when we realize we can also begin to desire these consequences our old "selves" previously did not consider or like. One's newfound capacity for desiring these things and one's new set of preferences shows that one has become a new kind of "self".

\section{SIMON, MARCH, AND HAYEK: CONNECTIONS}

Seen this way, design has the powerful potential to broaden human preferences. Indeed, Simon (1996) explicitly considers design something we should include in a curriculum for nurturing the liberally educated person. Design also helps us discover new conceptions of what "man" is, precisely because design helps us discover what new goals man can desire and pursue, and therefore exposes new interpretations of what it means to be human (ibid.). As mentioned earlier, the basis of such an intellectually exciting account of what design is and what it can do builds on Simon's recognition of our rationality's boundedness and with that, the need to search for what we cannot too easily know.

At the same time, with a footnote under the section on "Designing without final goals", Simon explicitly acknowledges a debt to James March (Simon, 1996, p. 162, n. 11). Indeed, March's (1978; 1994) own writings instantiate the same insight that we need to find strategic ways of exploring and searching for ideas that we are often blind to because of our cognitive limitations. There are many examples of these; I list a few. March's notion that there we should employ "technologies of foolishness" expresses the idea that we ought to set aside conventional ways of optimizing, consequentialist rationality in favor of risky exploratory acts. Thus he recommends that we "leap before we think", and suggests that we need a "catechism of heresy" to challenge entrenched orthodoxies (March, 1999, p. 227).
Again, he recommends welcoming "transitional hypocrisy" (March, 1995, p. 263) given that this may be an opportunity for exposing the agent to ideas he had not previously been sympathetic to. Elsewhere, he recommends reading great literature in order to discover logics that are different from the logic of consequences (see March, 1994; March \& Weil, 2005, pp. 85-86). Thus he commends to us Don Quixote, whose manner of thinking is ruled by a logic of appropriateness, and who is motivated by his conception of who he is, and what is appropriate to that identity, rather than by the most optimal course of action based on a projection of consequences (ibid.).

Yet Simon's attentiveness to bounded rationality and the need for searching discovery is equally, if not more, indebted to Ludwig von Mises and F. A. Hayek. We know that Simon was familiar with Mises's and Hayek's ideas because he refers to them when discussing rationality's limitations (Simon 1996, p. 34; March \& Simon, 1958, p. 172). Simon was familiar with Hayek's criticism of socialist central planning and interventionist monetary policies. By his own admission he was to draw more on Hayek's ideas than those of Mises's. In this short piece I also focus on Hayek's influence on Simon. In any event, Hayek (1988), following but clarifying and developing Mises' basic insights, argued that central planning was bound to fail, simply because central planners did not have the intelligence or rationality that could enable them allocate resources for a complex community. Hayek was keen to insist that our human ignorance meant that no central planner had the ability to know how best to give to each person what he needed to benefit himself, and what he needed to have to benefit others most optimally. Thus any central planning allocation of goods and services was bound to be very inefficient, leading to persons having in wasteful excess what they did not need, and others deprived of what they needed. The result would be poverty on a large scale. What he suggested instead was for the central planner to refrain from such planning allocation and let producers abduce or make educated guesses about what people around them needed while they signaled to others what they themselves needed. And the way to signal this was by way of their transacted prices. When goods and services are bought and sold, the exchange prices give us a sense of how much of these goods and services are needed. The higher the transacted price, or the more profitable, the more likely therefore is there a demand for that good or service, which means that entrepreneurs and producers should seek to produce more of these goods and services. The market prices of goods and services are like a kind of signaling system, which 
informs all those watching it what would be in demand in the marketplace (and hence what is needed), and what would not be in demand (and hence what is not needed). For this reason Hayek was critical of state intervention to regulate the prices of goods and services, because this interfered with this signaling system called the free market. If the free market price signals were distorted, the result would be that businesses could not have the right information to discern how best to coordinate their production plans with consumer needs and wants (Hayek, 1988).

Whatever one thinks about the moral merits of the free market, the more pertinent idea for our chapter concerns what Hayek says about the emergence of the free market system and its ability to coordinate the needs and wants of billions of people. It should be noted that most businessmen in the marketplace are not driven by any kind of moral altruism, but rather are driven by the profit motive. They are typically there not to help others, but really to help themselves to a piece of the pie. Yet their very human actions (driven by profit) led to the emergence of the free market mechanism that has many morally welcome benefits. Firstly, the coordinated production and consumption of goods and services leads to the eradication of mass poverty, which could very likely have resulted from inefficient central planning. Secondly, Hayek (1976, p.115) calls the free market not an "economy" so much as a "catallaxy", a word he coined but with etymological origins in a similar Greek word katallattein that meant "the art of making your enemies your friends". He meant by this that the free market had the ingenious ability to make friends of enemies. This is because persons of different aims and goals now become useful to each other in buying and selling when their exchange gives what is useful to the other person whose purposes they do not know, whereas if two person knew they had contradictory ends they would naturally have become enemies. In other words, their human actions would lead to consequences that the agents had not originally intended. More generally, Hayek observed that sometimes human actions led to desirable systems and institutions, such as the free market, producing welcome consequences that we had not intentionally "designed". These are spontaneous orders that evolved without any intentional designer. Hayek would later speak of "designing" for these undesigned systems like the free market, meaning that one plans to favor and not disrupt these beneficial systems which had evolved without any human design. This point is exactly mirrored by Simon's suggestion that designers should welcome unintended effects that they had not intentionally designed towards in order to integrate them as new final goals in a new design iteration.

\section{SIMON, MARCH AND HAYEK: DIFFERENCES}

Let us take stock. We have been unpacking Simon's account of "design without final goals" and his attentiveness to bounded rationality. This suggestion to designers to searchingly welcome unintended consequences as new design final goals has genetic parallels in James March's exploratory decision theory through technologies of foolishness as well as F. A. Hayek's political economy critical of central planning in favor of spontaneous orders. So there is the golden thread of the recognition of bounded rationality that unifies the theories of Simon, March and Hayek. But between them there remain important differences as each of them pressed their theories forward. These differences are to be found in the way Simon, March and Hayek's moral theories diverge and steer each of their design theories.

Let us start with Simon. Simon's early work was influenced by logical positivism, which he later recanted (Simon, 1997, p.68). However, throughout his life he consistently affirmed that reason cannot tell us what are the final ends we ought to seek when we design; we only have our desires to lead us (Simon, 1983, p.7). This idea derives from David Hume who argued that our ends are merely our desires, and that all that reason could do was to work out the means to achieve these desires. Indeed Hume is famously remembered as the person who said that reason is (and ought to be) the slave of our passions. Simon himself constantly spoke of the ends of our designs as our preferences, and the use of the word "preference" rather than "reasons" is indicative of Simon's Humean belief that reason has nothing to say about our ends. Ultimately therefore, when design expands our preferences, this means it helps us discover what else there is that we can like. Although in practice there can be a general consensus that some things are universally disliked and others are universally like-able, in principle Simon's design theory is amorally emotivist and inclined to moral relativism. In fact Simon's design theory welcomes the broadening - and hence alteration - of our set of preferences, and this means that it has the powerful ability to upstage current mores, and to upset the ethical status quo, with a view to introducing new normative, moral or cultural paradigms when it enables us to experience and assimilate new desires. 
Like Simon, March is also keen to introduce new cultures and ethical paradigms different to the current and dominant ethical paradigm. March's typical target amongst other ideas is consequentialism. Consequentialism is a manner of thinking which seeks to produce the best consequence, and one typically does this by projecting the kinds of possible futures made available by different courses of actions, and then choosing the one that brings us into that best future, whether this means the one in which we have the most of what we desire, or the least of what we do not desire. Simon himself was critical of consequentialist ways of deliberating when he argued that human rationality could not clearly see into the futures of our actions. At the same time Simon was unhappy with the way in which consequentialist thinking typically narrows the kinds of subjective utilities or what are the preferences that the agent desires. And for this very reason, when one designs without final goals, one can broaden the kinds of preferences one would regard as a subjective utility one can aim for. Still, while Simon sought to promote the search for new goals, he did not quite speak of the search for new ways of thinking. Although Simon did propose that agents satisfice rather than optimize, this is not so much because Simon was keen to introduce a new logic. Rather it was a grudging concession given the inability to optimize. If we could optimize, Simon would say we should do that, rather than satisfice.

This is where March is different from Simon. Supposing we could indeed optimize through consequentialist styles of deliberation, March would still have us seek an alternative to consequentialism. March was not merely interested in broadening our set of preferred desires, ends or goals, but also our styles of thinking. Thus rather than leave us to think with a "logic of consequences", March sought to introduce and highlight what he called the "logic of appropriateness" (March \& Weil, 2005, pp. 85-86). This latter, as mentioned earlier, required the agent to think of his or her duties appropriate to his or her identity and sense of "self", rather than the kinds of consequences that his or her actions would produce. Thus in On Leadership (March \& Weil, 2005), he commends to his readers the spirit of Don Quixote de la Mancha in the Spanish novel of the same name. Don Quixote, he points out, operates with a sense of duty, and draws from his sense of who he is. He thinks of himself as a knight, and his primary motivation is to reproduce the kinds of action that are appropriate for someone who is a knight (March \& Weil, 2005, pp. 85-86). This is something similar to, but not identical with Immanuel Kant's deontological moral philosophy, which points the moral agent to his duties. Kant referred to these duties as Categorical Imperatives, which the agent ought to fulfill regardless of the consequences. March also cites other thinkers to assert his pedigree, such as Søren Kierkegaard and Plato (see March 1994). In any event, March's response to human bounded rationality was to search for new logics altogether, and not merely new preferences and ends. In fact I would even go so far as to say that March is not merely seeking to broaden our styles of thinking - in some places he seems to think that the "logic of appropriateness" is favorable to the "logic of consequence". Thus when thinking through the design of the business school curriculum, he worries about the obsession with relevance, unpacked in terms of a "usefulness", concerned only with the production of desired consequences. In its place he suggests that we ought rather to think about what "education" is all about (March, 2008, pp. 407-408). Here we see him re-introducing and applying the logic of appropriateness when he inquires after what is appropriate to the task of education. He insinuates that education, even for a business school, should not so much be to deliver the relevantly useful, but should aim to engender the aims of education as prescribed by the "essence" of what education is, which he thinks is the love of the aesthetics of knowledge. He suggests that knowledge is beautiful in itself and that is what educators should aim to cultivate in our students, rather than what is merely useful for something else. Knowledge gained in education is not something merely to be used, but is something to be admired in itself. One could say in short that March favors the engineering or design of systems and behaviors that accord with the logic of appropriateness.

\section{Like Simon and March, Hayek's attentiveness} to bounded rationality also led him to affirm the importance of broadening preferences and logics, although much of these ideas are entangled with his own political theory. For Hayek (1988; 2014), the failure to acknowledge our own ignorance and our rationality's boundedness leads us to presume that we can centrally plan - design - our society, with dire consequences. If there is such presumptuous design-planning, which inevitably plans towards a narrowed set of goals that works best for accounting, then Hayek felt there ought to be put in place sources of disruption. Thus he often worried about how coercion by the state could narrow our minds and enslave them to a consequentialist manner of thinking directed to the purposes of some other person. For this reason he lamented when many were under the employment of the state. Whereas the wealthy man of independent means owning private property, he argued, was important culturally because he could in complete freedom sponsor 
and support new thinkers and ideas that emerge, and Hayek highlighted their importance in the strongest terms (Hayek, 2011, pp. 194-195). In other words, Hayek was attentive to the need to resist powers that narrowed thinking and the importance of encouraging sources of new ways of thinking. One could almost say, to paraphrase March, that the wealthy land owner of independent means was a source of desirable "heresy", and a system with strong private property rights embodied a technology of foolishness. More generally, it was important for Hayek that human beings could enjoy the freedom to discover new ideas and in this respect, Hayek was a liberal. Here one recalls how Simon also welcomed the liberally educated person when commending the practice of design without final goals, which welcomes unintended and desirable effects.

Still Hayek did not promote irresponsible, wanton revolution; paradoxically but very consistently he lamented that the beneficial moral beliefs of the monotheistic religions were no longer taken seriously, even though he did not himself believe these religions to be true (Hayek, 1988, pp. 136 -137). If anything Hayek consistently repudiated what he called "Cartesian constructivism". By that he meant the mistaken attitude that thinks ourselves able to build from scratch, with our own intelligence, all the moral and cultural systems which benefit us. Rene Descartes, we will remember, sought to build from scratch a complete epistemology and ontology in his Meditations on First Philosophy, and he did that first by doubting everything that could be doubted. For Hayek, this was a very bad idea when transposed into social and political theory. Many complex systems, such as the free market and the traditional rules of morality, evolved over many years to become the kinds of beneficial systems that they are without intentional human design (Hayek, 2014). It was not our intelligence that designed these; rather their coming to be was a result of our actions and their unintended consequences. It is only in hindsight that we can understand and admire them; in that sense our intelligence is a product of these systems. Our task is not to whimsically tear these apart but rather to appreciate and favor them. His fear of this kind of presumptuous planning also led him to repudiate "utilitarianism", which is a form of calculative, consequentialist planning in the ethical and political realm. However, unlike March he did not propose an alternative such as a "logic of appropriateness" because Hayek was interested in promoting good consequences primarily. Hayek's point is that, if we are to achieve the good consequences we desire, then ironically we should not be designing through calculative planning towards these in a fallacious spirit of Cartesian constructivism because as boundedly rational beings, we cannot. Instead we should design to protect and preserve the undesigned, spontaneous orders that evolved without human design. One could almost say that this was a historically informed endorsement of institutions which were the result of design without final goals, since these undesigned institutions were the products of the unintended consequences of other intentions or designs. Still, Hayek would probably remind us that such institutions were not "designed", and he would probably suggest we avoid characterizing these as products of design without final goals since that could invite confusion.

\section{CONCLUSION: OUTSMARTING OURSELVES}

To conclude, we have something to learn from all three thinkers about design, I believe. Although they differ in various ways, they all have this in common: their humble admission that we are plagued by human ignorance and that our rationality is bounded. We are not as smart as we wished we are. But all is not lost: our very own recognition of our bounded rationality is a key to outsmarting ourselves. And in all three thinkers we see them suggesting ways to get around or expand our limited intelligence.

Simon's suggestion that in design practice we can be open to new goals that emerge helps us overcome the fixation on goals currently available to our bounded rationality. March welcomes strategies to stimulate foolishness - if anything to design/engineer opportunities to encounter the new and different, in order to break through the barriers imposed by rationality's boundaries. Hayek alerts us to the need to appreciate spontaneous orders that arise not through human design and to favor them in our own social designs, rather than to seek to design society from scratch as central planners with bounded rationality only to make a mess of things.

This does not mean we should agree with everything they say. Given my own sympathies for Aristotle, Thomas Aquinas and John Finnis' new natural law theory (Finnis, 1980), I myself think Simon's axiology quite mistaken; human reasoning I would argue prescribes choice-worthy values as ends as much as it can help us discern the means to achieve these ends, and design should take these ends into account (see Finnis 1980; Chua 2011; Chua, in press). Also, March's work on the engineering/ design of "selves" sometimes risks coming too close to voluntarist accounts of the will, and his endorsement of Don Quixote concedes too much to arbitrary autonomy indifferent to the demands of moral rules and absolutes (see Chua, 2014). Hayek's 
own utilitarian defense of spontaneous orders I feel needs to be refined with a stronger emphasis on a robust account of common goods that reason can recognize thus requiring that, when designing our business models and social orders, we ultimately aim our enterprises at choiceworthy ends and eschew the obscene accumulation of merely monetary capital for its own sake (see Gregg, 2013) - a point which Hayek (1976, p. 136) did insinuate was worthy of attention but on behalf of which, unlike Marxists (see Harvey, 2010), he may not have sufficiently attended to (Finnis, 1998; Chua, 2012). Still, in the end their great contribution is to have broken the spell of the fictitious, omniscient homo economicus and its hold on a great many of us, and to point us in the direction of thinking about how to design ourselves around our admitted ignorance - a task that they left us to complete.

\section{ACKNOWLEDGMENTS}

I am grateful to two anonymous reviewers for their very detailed comments and criticisms which improved this paper substantially. All remaining errors are my own fault.

\section{REFERENCES}

Augier, M. \& March, J. G. (2008). The pursuit of relevance in management education. In James G March (Ed.), Explorations in organizations. Stanford: Stanford University Press.

Chua, S. M. J. (2009). Donald Schön, Herbert Simon and The Sciences of the Artificial. Design Studies 30(1), 60-68. http:// dx.doi.org/10.1016/i.destud.2008.09.001

Chua, S. M. J. (2011). Things to do on the play-ground: Topics for a catholic (universal) science of design. Angelicum 88(2), 557-579.

Chua, S. M. J. (2012). Schools as social enterprises: The Las Casas Report, evidence-based, and neoliberal policy discourse. Journal of Markets \& Morality, 15(2), 391-413.

Chua, S. M. J. (2014). Education, relevance and beauty: The spirit of democratic capitalism, orthodoxy, and the business school debate. In Samuel Gregg (Ed.), Theologian and philosopher of liberty: essays of evaluation and criticism in honor of Michael Novak (pp. 199-218). Michigan: Acton Institute.

Chua, S. M. J. (in press). Inclusive design research and design's moral foundations. In Paul Rodgers and Joyce Yee (Eds.), The Routledge companion to design research (pp. 5059). London: Routledge.

Coyne, R. (2005) Wicked problems revisited. Design Studies. 26(1), 5-17. http://dx.doi.org/10.1016/j.destud.2004.06.005

Cross, N. (2001). Designerly ways of knowing: Design discipline vs. design science. Design Issues, 17(3), 49-55. http://dx.doi. org/10.1162/074793601750357196

Finnis, J. (1980). Natural law and natural rights. Oxford: Clarendon Press.
Gregg, S. (2013) The Tea Party catholic. New Yok: Crossroads Publishing.

Harvey, D. (2010). The enigma of capital and the crisis of capitalism. New York: Oxford University Press.

Hayek, F. A. (1973) Law, legislation and liberty. Vol. 1 (Rules and order). London: Routledge and Kegan Paul.

Hayek. F. A. (1976) Law, legislation and liberty. Vol. 2 (The mirage of social justice). London: Routledge and Kegan Paul.

Hayek, F. A. (1988) The fatal conceit: The errors of socialism. Chicago: University of Chicago Press.

Hayek, F. A. (1994). The road to serfdom. Chicago: University of Chicago Press.

Hayek, F. A. (2011). The constitution of liberty. Chicago: University of Chicago Press.

Hayek, F. A. (2014). The result of human action but not of human design. In Bruce Caldwell (Ed.), Market and other orders. Chicago: University of Chicago Press.

March, J. G. (1978). Bounded rationality, ambiguity and the engineering of choice. The Bell Journal of Economics, 9(2), 587-608.

March, J. G. (1994). A primer on decision making: how decisions happen. New York: The Free Press.

March, J. G. (1999). The pursuit of organizational intelligence. Oxford: Blackwell.

March, J. G. \& Simon, H. A. (1958). Organizations. Oxford: Blackwell.

March, J. \& Weil, T. (2005). On leadership. Oxford: Blackwell.

Rittel, H. \& Weber, M (1973). Dilemmas in a General Theory of Planning. Policy Sciences, 4, 155-169.

Schön, D. (1983) The reflective practitioner: how professionals think in action. London: Temple Smith.

Simon, H. A. (1975) Style in design. In C. Eastman (Ed.), Spatial Synthesis in Computer-Aided Building Design (pp. 287-309). New York: John Wiley.

Simon, H. A. (1983). Reason in human affairs. Oxford: Blackwell.

Simon, H. A. (1996). The sciences of the artificial (3rd Edition). Cambridge, Mass.: MIT Press.

Simon, H. A. (1997). Administrative behavior (4th Edition) London: The Free Press.

\section{CORRESPONDENCE}

Jude Chua Soo Meng

Policy and Leadership Studies AG

National Institute of Education, Nanyang

Technological University, Singapore

1 Nanyang Walk, Singapore 637616

E-mail: jude.chua@nie.edu.sg

Published online 28 July, 2015

ISSN 1749-3463 print/ISSN 1749-3471

http://dx.doi.org/10.14434/artifact.v3i4.12787

(C) 2015 Artifact 